\title{
International Business Tourism: A Growth Rate Model
}

\author{
${ }^{1}$ Pedro Carvalho, ${ }^{2}$ Miguel A. Márquez, ${ }^{3}$ Montserrat Díaz \\ ${ }^{1}$ School of Technology and Management, Polytechnic Institute of Viana do Castelo, Portugal \\ ${ }^{2}$ Faculty of Economics and Business Administration, University of Extremadura, Spain \\ ${ }^{3}$ Faculty of Economics and Business Administration, University of Extremadura, Spain \\ ${ }^{1}$ pc@estg.ipvc.pt, ${ }^{2}$ mmarquezunex@gmail.com, ${ }^{3}$ mdmendez@unex.es
}

\begin{abstract}
The aim of this paper is to understand the factors influencing business tourism on a global scale, in order to assess the competence of the countries in this tourism segment and prescribe them guidelines for action. For the development of data analysis, a growth rate model was estimated and a sample of 136 countries for the years 2005 and 2009 was collected. Results reveal that, for the development of policies to stimulate the growth in the business tourism segment, countries should develop measures that encourage capital investment in tourism, leisure tourism and trade openness.
\end{abstract}

Keywords: business tourism; convention tourism; planning policy; economic growth

\section{INTRODUCTION}

Business tourism, in the international context, is an important tourism segment. According to the World Travel and Tourism Council ${ }^{1}$, in 2014, the revenue from business tourism worldwide totalled U.S. \$ 1175.67 billion, representing, in the same year, about $31 \%$ of the revenues resulting from leisure tourism. The scientific community has also highlighted that business tourism grants countries several benefits of an economic, social and cultural nature (Wootton and Stevens, 1995; Bradley, Hall and Harrison,2002; Crouch and Louviere, 2004; Guizzardi, 2005; Haven-Tang, Jones and Webb, 2007; Bernini, 2009).

It should also be noted that several researchers still express the need for further research in this area of knowledge, evoking that the research already developed in other segments of tourism may not be the most appropriate, given the specific characteristics associated with business tourism (Oppermann, 1996; KulendranandWitt, 2003; Hankinson, 2005;DiPietroet al.,2008; Pike, 2008; Judith and Thompson, 2009; Bernini, 2009).

This reality should lead to a discussion by business organizations and policy makers on the effectiveness of the strategy developed, as well as a clear understanding of the factors that allow countries gaining market share in this tourism segment worldwide. On the other hand, most studies in this field have focused on the analysis of this sector using specific attributes associated to a consumer behaviour approach, and some of them have used a macro determinants approach (Var, Cesarioand Mauser, 1985; Kulendran and Witt, 2003), supplementing (the aggregated variables) the analytical perspective of economic agents and political decision-makers of tourist destinations.

This article aims at contributing to the understanding of the (macro) determinants influencing travel and business tourism, in order to assess countries' touristic competence in the business tourism segment and prescribe them a set of strategic guidelines for growth in this market segment. To fulfil the stated objective, a regression model by the method of ordinary least squares is estimated, using the collection of a sample of 136 countries for the years 2005 and 2009, and explanatory variables usually included in the economic literature are used.

\section{LiTERATURE REVIEW}

The phenomenon of business travel can lead to the use of free time, during the period of stay in the visited country, to carry out cultural, shopping and leisure activities. Therefore, business travel often becomes one of the various types of tourism (Cunha, 1997). Although the scientific community is not

${ }^{1}$ Database online at:http://www.wttc.org/research/economic-data-search-tool/ 
unanimous in terms of the concepts, business travel should not be confused with business tourism. Thus, how should we understand the concept of business tourism?

Davidson and Cope (2003) demonstrate, in a joint research, how the concepts may be distinguished. According to them, business travel aggregates individual business travel and business tourism. On the other hand, business tourism should be understood as travels involving the presence of several people, in order to participate in collective business meetings, exhibitions or incentive travels. Therefore, the authors explain that business travel includes the following types of events:

- Individual business travels, comprising the travels made by people whose employment requires travel in the course of their work;

- Meetings, including a huge variety of events, namely conferences, training seminars, product launch and annual general meetings held by companies;

- Exhibitions, also known as fairs for professionals and general public;

- Incentive travels, comprising the travels made by employees in the form of bonuses associated to their performance;

- Corporate hospitality, consisting of entertainment that many companies grant, for example, to their actual or potential customers, usually associated with sports and cultural events.

According to Davidson and Cope (2003), business tourism canbe seen as the travels that compose the MICE industry - Meetings, Incentives, Conferences and Exhibitions. However, the existence of different purposes associated to the business tourist should lead to a reflection about the factors influencing the demand in this tourism segment.

From the late 80 s onwards, the determining factors associated with individual participation in a collective business meeting (MICE)have received particular attention from researchers of this field of studies(Oppermann and Chon, 1997; Lee and Park, 2002; Zhang, Leung and Qu,2007; Severtet al.,2007; Judith and Thompson, 2009; Shin, 2009; YooandZhao, 2010; Draper, Dawson and Casey, 2011; Sox et al, 2013; Fenichet al.,2014; Whitfield et al.,2014), as well as the factors valued by companies and associations concerning the choice of location for business meetings' purposes, as we shall see.

\subsection{Determinants Associated with the Choice of Location by Companies and Associations}

In 1985, three American researchers developed a study linked to the meetings market for associations in 52 north-American cities, seeking to understand the determinants of participation in conventions in a domestic context (Var, Cesario and Mauser, 1985). These researchers have concluded that there are three variables influencing the level of interest in participating in a convention: accessibility, emissiveness (combined effects of differentiating characteristics, such as income and population of origin state) and attractiveness (i.e., facilities, climate, availability of leisure and cultural activities).

In the 90s, following an approach related to the attribute analysis of convention destinations, the work carried out by Oppermann (1996) and Crouch and Ritchie (1997) is to be highlighted. Considering a selection of 30 convention destinations, Oppermann (1996) concluded that the most relevant attributes in the choice of destination by meeting organizers for associations are: service, cost, image, location and facilities. Two years later, Crouch and Ritchie (1997), based on an extensive literature review, identified conceptually the factors influencing the choice of location for the convention by the associations, and found the following new dimensions: accessibility, local support, extra-conference opportunities, accommodation facilities, meeting facilities, information, site environment and other criteria (such as natural risks and risks associated with the possibility of war, boycotts and other adverse events, profitability of convention and the very novelty of the destination).

At the beginning of the new millennium, new studies have been carried out in this field of knowledge. For example, Bradley,Hall and Harrison(2002), in a study associated with the choice of location to carry out individual meetings, have identified eight categories of determinants: cultural factors; social factors; environmental factors; political factors,; regeneration/economic development factors (associated with the perception of the success of recent urban regeneration projects); factors specifically related to the individual venues; factors specifically related to the facilities (hotels, shops, etc.) in the venue's location; and accessibility factors. Meanwhile, Crouch and Louviere (2004), in a 
study related to association meetings in the Australian market, concluded that the determinants in the choice of location are associated to: convention venue and facilities; travel distance; cost and site accessibility; accommodation location and costs; and site environment and local assistance.

Further studies have been developed by reputed researchers in the first decade of the second millennium (Hankinson, 2005; Chen, 2006; Haven-Tang,Jones and Webb,2007; DiPietroet al., 2008), from which the work developed by Hankinson (2005) stands out. This researcher explains that the brand image of a business destination results from eight clusters of attributes linked to the business destination: physical environment; economic activity (holiday tourism, industries, economic regeneration and commerce); accessibility; social facilities (shops, restaurants, clubs and pubs); strength of reputation (prestige of the destination and marketing strategies of the destination); people characteristics; and perceived size of a destination.

Following a macroeconomic approach, Kulendran and Witt (2003), in a study related to a comparison of demand forecasting methods in international business tourism, presented as explanatory variables: economic activity in the origin country (an increase may stimulate the demand of imports and may result in business tourism abroad); economic activity in the destination country (may result in an increase of exports from the origin to the destination country and, therefore, in business travel to the destination country); holiday price in the destination country; trade openness among countries (the reduction of protective devices leads to more opportunities for international trade and for business tourism); and the volume of holiday tourism (holiday tourists may become business tourists, once they may become aware of business opportunities while visiting the destination).

Over the last decade, new studies have also been published (Dragičevićet al., 2012; Parket al.,2014; Huang, 2015), most notably, in recent published works, a study published in the Journal of Convention \& Event Tourism by Park et al. (2014). The researchers identified five categories of determinants in the selection of the convention site: destination characteristics; convention facilities and partnership opportunities; experience and services; government and policies; and price levels, taking into consideration a study carried out in China by several meeting planning professionals.

In the literature review, we identify determinants related to the choice of location by companies and associations, which may be classified into determinants related to the (i) country of origin, such as, origin country income, economic activity in the origin country and emissiveness (combined effects of differentiating characteristics such as income, population, etc...) and (ii) determinants related to the country of destination. Considering the determinants related to destination, there are some determinants that may be controlled by the action of economic agents and political decision-makers. Moreover, there is a variety of determinants that are beyond the capacity of being influenced by the various actors, due to reasons that are natural, historical or alien to the destination country (i.e., climate, natural disasters, natural landscape, popular culture, geographic location, distance from attendants, historic buildings, monuments, among others). In this way, there are determinants liable to be controlled by institutional actors that may influence business tourism at the tourist destination: (i) the monetary vacation cost in the destination country (the monetary expense of transportation and access, the cost of suitable accommodation and the cost of the meeting space);(ii) the equipment for business meetings(the availability and ability of the site to provide suitable sized facilities and service quality); (iii) security(the place provides a safe political environment, a secure social environment and a weak possibility of strikes, boycotts and other possible adverse events); (iv) the dynamism of industry, trade, tourism and leisure services; (v) the infrastructure(the suitability and standard of local infrastructure); (vi) the ability of urban, commercial and economic regeneration;(vii) the hospitality(associated with residents' qualification and preparation for tourism); (viii) the accessibility of the site (in particular, the connections to the business destination and the infrastructure for transport); (ix) the equipment rooms(the number of rooms available and the perception of the standards of service); (x) the opportunities for culture and recreation(museums, monuments, parks, local tours, historical sites, theaters, bars, restaurants, nightclubs, sports and activities, either as spectator or participant); and (xi) the degree of economic opening of the destination country in relation to the outside world(influencing the trading relationship between countries, namely negotiations, business deals and selling, among others).

Therefore, according to the assertions presented, it is possible to understand that the performance of a tourist destination depends on the actions of institutional actors on that destination. Thus, this reflection allowed us developing the following research question: Which are the determinants 
influencing the demand evolution, in the short and medium term, of travel and business tourism that may be controlled by economic agents and policy makers of destination countries?

\section{METHODOLOGY}

\subsection{Sample and Technical Analysis}

For the last five years of the past decade, a representative sample collection of the main destinations for business tourism in the global context was carried out and, for the purposes of its incorporation, data from 136 countries concerning the years 2005 and 2009 were collected $^{2}$, provided by World Travel and Tourism Council, DataWorld Bank and Worldwide Governance Indicators (integrated into the World Bank). Data analysis was carried out using the estimation of an econometric model of growth rates, by the method of ordinary least squares. To make the modelling and estimation of thedatamodel,theEviews6.0software was used after the construction of the data table in Microsoft Office 2010Excelsoftware. The estimation of the model implied the need to verify compliance with the classical assumptions of multiple regression (Gujarati, 1995).

\subsection{Dependent and Explanatory Variables}

As dependent variable - business travel and tourism spending -is proposed, which can be obtained from the World Travel and Tourism Council (WTTC) through the database available online. ${ }^{3}$ According to the WTTC (2011), it consists of business trips spending made within a country by residents and international visitors. However, it is noteworthy that the data for this variable are subject to the incorporation of the Gross Domestic Product (GDP) deflator of the corresponding countries (from the base year 2002). ${ }^{4}$

Following the existing literature and the controlled determinants influencing business tourism, different explanatory variables are introduced into the analysis. Thus, we present the explanatory variables considered:

- For the vacation cost in the country of destination, the variable cost of living is proposed, which will be handled from the proxy ratio - conversion factor of purchasing power parities to the market exchange rates. This ratio is the result obtained by dividing the conversion factor of purchasing power parities by the market exchange rate;

- The variable government effectiveness will operationalize the factor related to the opportunities for entertainment and culture resulting from public investment, hospitality associated with the qualification of the residents and the quality of public services and general infrastructure, while promoting aspects of economic activity dynamism and the visitor's accessibility;

- The variable capital investment will operationalize the opportunities for entertainment and culture resulting from private investment, investment in accommodation and meeting facilities, and connections of private companies to the destination / location of the meeting (related to the accessibility dimension). However, it is worth noting that the data will be subject to the incorporation of the GDP deflator for the respective countries, in order to obtain a time series with real data (base year 2002);

- For safety policy and social security, the variables political stability and rule of law, respectively, are proposed; the variable regulatory quality will operationalize the ability of economic, commercial and urban regeneration of the countries promoted by public authorities;

- The variable leisure travel and tourism spending explains the dynamism of leisure tourism and can be measured on the basis of the spending on travel and leisure tourism adjusted by the GDP deflator (base year 2002);

- The variable economic activity (GDP) aims to operationalize the dynamism of public and private sectors (in particular, the industry, trade and services) of the economic activity and

\footnotetext{
${ }^{2}$ In order to proceed with sample homogenization, are excluded, from the sample, countries that had missing values in the reference years.

${ }^{3}$ Database online at:http://www.wttc.org/research/economic-data-search-tool/
}

${ }^{4}$ The GDP deflator was provided by Data Word Bank from the series of Economic Policy and External Debt, available at: http://data.worldbank.org/indicator/all 
generate added value for the tourist, and will be measured on the basis of the real GDP indicator built from the GDP at constant prices (base year 2002);

- The degree of economy openness in relation to the outside world will be operationalized with the variable trade openness (degree of trade openness in relation to the outside world) and the variable foreign direct investment(degree of financial liberalization). The first variable can be measured on the basis of imports plus exports from the country of destination in relation to the GDP of the country of destination (Kulendran and Witt, 2003; Lloyd and MacLaren, 2002; Aizenman and Noy, 2006). The second variable will be tested as the inflow of net investment by foreign investors in relation to GDP (percentage of GDP), in line with the work developed by Aizenman and Noy (2006) and Azman-Saini, Baharumshah and Law(2010).

So as to allow a better understanding, Table 1 summarizes the units of measurement associated with the dependent and explanatory variables.

Table1. Units of Measurement Associated with the Variables

\begin{tabular}{|c|c|}
\hline Variables & Units of measurement \\
\hline \multirow{2}{*}{ Business Travel and Tourism Spending } & $\underline{U S \$ b n(B T T S)}$ where $G D P$ \\
\hline & GDP constant 2002 US $\$$ \\
\hline \multirow{2}{*}{ LivingCosts } & Purchasing Power Parity \\
\hline & Market Exchange Rate \\
\hline Capital Investment & 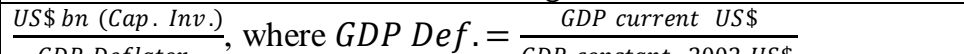 \\
\hline Political Stability & $\begin{array}{l}\text { The indicator is measured in units ranging from about }-2.5 \text { to } 2.5 \text {, } \\
\text { with higher values corresponding to better outcomes }\end{array}$ \\
\hline Rule ofLaw & $\begin{array}{l}\text { The indicator is measured in units ranging from about }-2.5 \text { to } 2.5 \text {, } \\
\text { with higher values corresponding to better outcomes }\end{array}$ \\
\hline GDP & GDP 2002 constant US\$ \\
\hline RegulatoryQuality & $\begin{array}{l}\text { The indicator is measured in units ranging from about }-2.5 \text { to } 2.5 \text {, } \\
\text { with higher values corresponding to better outcomes }\end{array}$ \\
\hline GovernmentEffectiveness & $\begin{array}{l}\text { The indicator is measured in units ranging from about }-2.5 \text { to } 2.5 \text {, } \\
\text { with higher values corresponding to better outcomes }\end{array}$ \\
\hline \multirow{2}{*}{ LeisureTravel\&TourismSpending } & US\$bn (LTTS) where GDP Def \\
\hline & HCIC UDF DEJ.- GDP constant 2002 US\$ \\
\hline Foreign Direct Investment & $F D I=\% G D P$ \\
\hline \multirow[t]{2}{*}{ Trade Openness } & Imports + Exports \\
\hline & $G D P$ \\
\hline
\end{tabular}

Source: Own elaboration

\subsection{Data Sources of the Explanatory Variables}

Considering the explanatory variables put forward, we present the sources of data collection considered: Two explanatory variables - capital investment and leisure travel and tourism spending come from the World Travel \& Tourism Council through the database available online. Cost of living (proxy ratio of purchasing power parities to market exchange rate), economic activity (GDP), trade openness (imports plus exports in relation to the GDP) and foreign direct investment are variables that can be obtained from the Data World Bank. ${ }^{5}$ Finally, the governance variables for government effectiveness, political stability, absence of violence and regulatory quality come from the Governance Indicators provided by the World Bank. ${ }^{6}$

\subsection{Econometric Model Specifications}

The mathematical specification is translated as a function of the evolution of short and medium term variables (growth from 2005 to 2009). This specification has the advantage of dealing with the problem of correlation caused by economic variables of trend and overcome the problem of spurious regression results (Song and Witt, 2000). For this reason, the econometric equation function that aims to shape the tourism offer will be estimated as:

$\Delta B T T S_{i}=\alpha+\beta \Delta X_{i}+\varepsilon_{i}(1)$

\footnotetext{
${ }^{5}$ Provided by Data World Bank at:http://data.worldbank.org/indicator/all

6 These governance indicators, elaborated by Kaufmann, Kraay\&Mastruzzi (2008) can be found at: http://info.worldbank.org/governance/wgi/
} 
where the dependent variable $B T T S_{i}$ consists of spending on travel and business tourism in the country $i, \alpha$ is a constant, $\beta$ is the parameter to be estimated, $X_{i}$ is the set of variables that influence each country $i$ the dependent variable $B T T S_{i}$ and $\varepsilon_{i}$ is a vector $\left(\mathrm{N}^{*} 1\right)$ of independent and identically distributed residuals, with a mean 0 and common variance $\delta_{\varepsilon}^{2}$.

\section{Results}

\subsection{Estimation of the Econometric Model}

From the sample, the specified model $(1)$ is estimated by the method of ordinary least squares, whose estimation results are depicted in Table 2 .

The results allow verifying that the overall regression is significant $(F=7.905391, p<.001)$, and so are significant individual variables in capital investment $(t=4.670757, p<.001)$, leisure travel and tourism spending $(t=2.139127, p<.05)$ and trade openness $(t=3.986831, p<.001)$. It should also be noted that the independent variables in the model explain almost $39 \%$ of the variation in business travel and tourism spending-BTTS $\left(\mathrm{R}^{2}=0.387417\right)$.

The results of the first estimation also meet the classical assumptions of multiple regression. In fact, the White's test $(F=0.614301, p>.05)$ and the Breush-Pagan-Godfrey test $(F=0.835382, p>.05)$ allow checking the absence of heteroscedasticity, as well as the variance inflation factor of the explanatory variables (VIF) and the condition index $(C I=4,341328)$ to ascertain the existence of a weak multicollinearity (Gujarati, 1995, 2004). On the other hand, the Jarque-Berra test rejects the null hypothesis that the residues are normally distributed $(J B=11.68802, p<.01)$. However, the overall and individual significance are still valid asymptotically since it is a large sample $(\mathrm{n}=136)$, and, consequently, the estimators obtained are still normally distributed asymptotically (Gujarati, 1995).

Table2. First Estimation: Ordinary Least Squares Regression

\begin{tabular}{|c|c|c|c|c|}
\hline \multicolumn{3}{|c|}{ Dependent Variable: Business Travel and Tourism Spending } & & \\
\hline \multicolumn{3}{|c|}{ Includedobservations: 136} & & \\
\hline Variable & Coefficient & Std. Error & t-Statistic & Prob. \\
\hline Constant & 0.031932 & 0.036919 & 0.864914 & 0.3887 \\
\hline Capital Investment & 0.148301 & 0.031751 & 4.670757 & $0.0000 * *$ \\
\hline ForeignDirectInvestment & -0.007631 & 0.005725 & -1.332858 & 0.1850 \\
\hline GDP & 0.130064 & 0.165511 & 0.785829 & 0.4335 \\
\hline GovernmentEffectiveness & 0.022103 & 0.020488 & 1.078826 & 0.2827 \\
\hline TradeOpenness & 0.688723 & 0.172749 & 3.986831 & $0.0001 * *$ \\
\hline LeisureTravel\&TourismSpending & 0.129707 & 0.060635 & 2.139127 & $0.0344 *$ \\
\hline LivingCosts & 0.225703 & 0.179851 & 1.254940 & 0.2118 \\
\hline PoliticalStability & 0.002110 & 0.003298 & 0.639760 & 0.5235 \\
\hline Rule ofLaw & -0.015783 & 0.021313 & -0.740554 & 0.4604 \\
\hline RegulatoryQuality & -0.032524 & 0.022380 & -1.453283 & 0.1487 \\
\hline R-squared & 0.387417 & \multicolumn{2}{|c|}{ Meandependent var } & 0.151089 \\
\hline Adjusted R-squared & 0.338410 & \multirow{2}{*}{\multicolumn{2}{|c|}{ S.D. dependent var }} & 0.329555 \\
\hline S.E. ofregression & 0.268054 & & & 0.282165 \\
\hline Sum squaredresid & 8.981603 & \multicolumn{2}{|c|}{$\begin{array}{l}\text { Akaikeinfocriterion } \\
\text { Schwarzcriterion }\end{array}$} & 0.517748 \\
\hline Log likelihood & -8.187239 & \multicolumn{2}{|c|}{ Hannan-Quinncriter. } & 0.377900 \\
\hline F-statistic & 7.905391 & \multicolumn{2}{|c|}{ Durbin-Watson stat } & 2.072305 \\
\hline Prob(F-statistic) & 0.000000 & & & \\
\hline
\end{tabular}

Source: Own elaboration

After removing non-significant variables, a new estimation is made, which reveal sheteroscedasticity problems, by applying the White's test $(\mathrm{F}=2.555810, \mathrm{p}<.01)$. Consequently, the White's corrected standard errors is applied to this estimation and the corrected estimation is obtained (Table 3).

The results of the second estimation of the model specified ( 1 ) show that regression is globally significant $(F=23.76261, p<.001)$ and that the new estimation of the model explains in $35.06 \%$ the variation of business travel and tourism spending $\left(\mathrm{R}^{2}=0.350674\right)$. On the other hand, the capital investment ( $t=5.366375, p<.001)$, leisure travel and tourism spending $(t=4.553600, p<.001)$ and trade openness $(t=2.818088, p<.01)$ are individually significant variables. 
Table3. Second estimation: ordinary least squares regression

\begin{tabular}{|c|c|c|c|c|}
\hline \multirow{2}{*}{\multicolumn{3}{|c|}{$\begin{array}{l}\text { Dependent Variable: Business Travel and Tourism Spending } \\
\text { Includedobservations: } 136\end{array}$}} & & \\
\hline & & & & \\
\hline \multicolumn{5}{|c|}{ White Heteroskedasticity-Consistent Standard Errors \& Covariance } \\
\hline Variable & Coefficient & Std. Error & t-Statistic & Prob. \\
\hline Constant & 0.063377 & 0.033049 & 1.917650 & 0.0573 \\
\hline Capital Investment & 0.161647 & 0.030122 & 5.366375 & $0.0000^{* *}$ \\
\hline LeisureTravel\&TourismSpending & 0.173168 & 0.038029 & 4.553600 & $0.0000 * *$ \\
\hline TradeOpenness & 0.540951 & 0.191957 & 2.818088 & $0.0056^{*}$ \\
\hline R-squared & 0.350674 & \multicolumn{2}{|c|}{ Meandependent var } & 0.151089 \\
\hline Adjusted R-squared & 0.335917 & \multicolumn{2}{|c|}{ S.D. dependent var } & 0.329555 \\
\hline S.E. ofregression & 0.268558 & \multicolumn{2}{|c|}{ Akaikeinfocriterion } & 0.237474 \\
\hline Sum squaredresid & 9.520315 & \multicolumn{2}{|c|}{ Schwarzcriterion } & 0.323140 \\
\hline Log likelihood & -12.14821 & \multirow{2}{*}{\multicolumn{2}{|c|}{$\begin{array}{l}\text { Hannan-Quinncriter. } \\
\text { Durbin-Watson stat }\end{array}$}} & 0.272286 \\
\hline F-statistic & 23.76261 & & & 1.985956 \\
\hline Prob(F-statistic) & 0.000000 & \multicolumn{2}{|c|}{ Durbin-Watson stat } & \\
\hline
\end{tabular}

Source: Own elaboration

\section{Conclusions}

This article seeks to offer a better understanding of the determinants that may be controlled in the short and medium term by economic agents and policy makers of destination countries, in order to assess touristic competence of the countries in the business tourism segment and prescribe them a set of strategic guidelines to gain market share.

Results show that capital investment, leisure travel and tourism spending, and trade openness of countries are variables that explain the behaviour of spending on international travel and business tourism in the short and medium term.

The variable capital investment is intended to measure private investment in accommodations, catering, cultural and sports equipment, and private investment in transport equipment specifically for touristic purposes. These results corroborate the results attained by various authors on the importance of the quality and availability of equipment for accommodation (Oppermann, 1996; Crouch and Ritchie, 1997; Bradley, Hall and Harrison,2002; Crouch and Louviere, 2004; Hankinson, 2005; Chen, 2006; Zhang,Leung and Qu,2007, DiPietro et al., 2008), equipment for catering and similar, entertainment and culture (Crouch and Ritchie, 1997; Bradley, Hall and Harrison,2002; Crouch and Louviere, 2004; Hankinson, 2005; DiPietroet al., 2008) and accessibility (Var,Cesario and Mauser,1985; Crouch and Ritchie, 1997; Bradley, Hall and Harrison, 2002; Hankinson, 2005; DiPietroet al., 2008).

The leisure travel and tourism spending explains the dynamism of leisure tourism of countries. Furthermore, according to the results, the looming of several researchers about the influence of leisure tourism in business tourism is confirmed (Kulendran and Witt, 2003; Hankinson, 2005). In fact, a destination of international business can, thus, benefit from the formation of a positive image created by leisure tourism (Oppermann, 1996 b; Page, 2003; Hankinson, 2005;DiPietroet al., 2008).

The degree of trade openness in relation to the outside world explains the component of international trade associated with commercial transactions, that is, exports and imports of goods and services (Keith, 2007) in relation to the country's GDP. Results show that the greater the flow of imports and exports in relation to the country's GDP, the more the economy is exposed to the outside world and the larger is the flow of travel and business travellers (Kulendran and Witt, 2003).

This information is important for economic agents and policy makers to implement strategies in the short and medium term that allow them gaining market share in their business destination: firstly, these actors must develop strategies to promote business tourism integrated with leisure tourism. Secondly, policy makers must develop policies to assist national companies in the export of goods and services (thereby stimulating the increase in commercial activity between countries) and develop policies that encourage private investment in fixed capital in tourism. Lastly, in line with this idea, economic agents should also focus their investments in equipment that creates value throughout the tourism supply chain, in particular, in transport and equipment for entertainment and culture.

The research carried out may be improved, namely by gathering data from other countries, given that a large number of countries, in particular associated with less developed economies, ended up having 
a smaller representation in this study.A panel data analysis mayallow identifying and measuring effects that are not detectable in time-series data or cross-section data (Baltagi, 2008).

\section{REFERENCES}

AIZENMAN, J. andNOY, I. (2006). FDI and Trade - Two-way Linkages?.The Quarterly Review of Economics and Finance, 46, 317 - 337.Doi: 10.1016/j.qref.2006.02.004

AZMAN-SAINI, W.N.W, BAHARUMSHAH, A. Z. and LAW, S. H. (2010). Foreign Direct Investment, Economic Freedom and Economic Growth: International Evidence. Economic Modelling, 27, 1079 - 1089.Doi:10.5539/ibr.v8n2p42

BALTAGI, B. H. (2008). Econometric Analysis of Panel Data ( $4^{\text {th }}$ ed.). West Sussex: John Wiley \& Sons.

BERNINI, C. (2009). Convention Industry and Destination Clusters: Evidence from Italy. Tourism Management, 30(6), 878 - 889.Doi:10.1016/j.tourman.2008.12.004

BRADLEY, A., HALL, T. andHARRISON, M. (2002). Selling Cities: Promoting New Images for Meetings Tourism. Cities, 19(1), 61 - 70.Doi: http://dx.doi.org/10.1016/S0264-2751(01)00046-4

CHEN, C.-F. (2006). Applying the Analytical Hierarchy Process (AHP) Approach to Convention Site Selection. Journal of Travel Research, 45(2), 167 - 174.Doi: 10.1177/0047287506291593

CROUCH, G. and LOUVIERE, J. (2004). Convention Site Selection: Determinants of Destination Choice in The Australian Domestic Conventions Sector. Australia:CRC for Sustainable Tourism Pty Ltd. Retrieved from: http://sustain.pata.org/wp-content/uploads/ 2015/02/ Crouch3 3011_ConventionSites.pdf

CROUCH, G. andRITCHIE, J. R. B. (1997). Convention Site Selection Research: A Review, Conceptual Model and Propositional Framework. Journal of Convention and Exhibition Management, 1, 49 - 69.Doi:10.1300/J143v01n01_05

CUNHA, L. (1997). Economia e Política do Turismo. Amadora: McGraw-Hill.

DAVIDSON, R. andCOPE, B. (2003).Business Travel: Conferences, Incentive Travel, Exhibitions, Corporate Hospitality and Corporate Travel. Essex: Pearson Education.

DIPIETRO, R. B., BREITNER, D., ROMPF, P. andGODLEWSKA, M. (2008).An Exploratory Study of Differences among Meeting and Exhibition Planners in their Destination Selection Criteria.Journal of Convention \& Event Tourism, 9(4), 258 - 276.Doi:10.1080/ 1547014080 2473689

DRAGIČEVIĆ, V., JOVIČEVIĆ, D., BELŠIĆ, I., STANKOV, U. andBOŠKOVIĆ, D. (2012). Business Tourism Destination Competitiveness: A Case of Vojvodina Province (Serbia). Economic Research - EkonomskaIstraživanja, 25(2), 311 - 332.Doi: 10.1080/ 1331677 X.2012.11517510

DRAPER, J., DAWSON, M. andCASEY, E. (2011).An Exploratory Study of the Importance of Sustainable Practices in the Meeting and Convention Site Selection Process. Journal of Convention and Event Tourism, 12(3), 153 - 178.Doi: 10.1080/15470148.2011.598353

FENICH, G., SCOTT-HALSELL, S.,OGBEIDE, G.-C. and HASHIMOTO, K. (2014). What the Millennial Generation from Around the World Prefers in Their Meetings, Conventions and Events. Journal of Conventions and Event Tourism, 15, 236 - 241.Doi:10.1080/ 15470148.2014.929993

GUIZZARDI, A. (2005). A New Approach in Business Travel Survey: Multivariate Techniques for Strata Design. In M. Vichi, P. Monari, S. Mignani, and A. Montanari (Eds.), New Developments in Classification and Data Analysis (pp. 311-316). Heidelberg: Springer.

GUJARATI, D. (1995). Basic Econometrics (3rd ed.). New York: McGraw-Hill.

GUJARATI, D. (2004). Econometría (4ta ed.). México: McGraw-Hill.

HANKINSON, G. (2005). Destination Brand Images: A Business Tourism Perspective. Journal of Services Marketing, 19(1), 24 - 32.Doi: 10.1108/08876040510579361

HAVEN-TANG, C., JONES, E. andWEBB, C. (2007).Critical Success Factors for Business Tourism Destination.Journal of Travel \& Tourism Marketing, 22(3/4), 109 - 120.Doi: 10.1300 /J073v22n03_09

HUANG, H.-C. (2015). How Does Meetings, Incentives, Conventions and Exhibitions Industry Attract Exhibitors?.Asia Pacific Journal of Tourism Research, Doi: 10.1080/ 10941665.2015.1016444. 
JUDITH, M. and THOMPSON, K. (2009).The UK Association Conference Attendance DecisionMaking Process. Tourism Management, 30(3), 400 - 409.

KAUFMANN, D., KRAAY, A.and MASTRUZZI, M. (2008).Governance matters VII: governance indicators for 1996-2007. World Bank Policy Research. Retrieved from http://info.worldbank.org/governance/wgi/GovernanceMattersVII.pdf

KEITH, H. (2007). Elements of Multinational Strategy. Heidelberg: Springer.

KULENDRAN, N. andWITT, S. (2003). Forecasting the Demand for International Business Tourism".Journal of Travel Research, 41(3), 265 - 271.Doi: 10.1177/0047287502239034

LEE, T. H. and Park, J.-Y. (2002). Study on the Degree of Importance of Convention Service Factors: Focusing on the Differences in Perception Between Convention Planners and Participants. Journal of Convention \& Exhibition Management, 3(4), 69 - 85.Doi: 10.1300/J143v03n04_04

Lloyd, P.J. and MACLAREN, D. (2002).Measures of Trade Openness Using CGE Analysis. Journal of Policy Modeling, 24, 67 - 81.Doi: 10.1016/S0161-8938(01)00096-5

OPPERMANN, M. (1996). Convention Destination Images: Analysis of Association Meeting Planners' Perceptions. Tourism Management, 17(3), 175 - 182. Doi: http://dx.doi.org/10.1016/0261-5177(96)00004-0

OPPERMANN, M. (1996 b).Convention Cities - Images and Changing Fortunes. The Journal of Tourism Studies, 7(1), 10 - 17.

OPPERMANN, M. and CHON, K.-S.(1997). Convention Participation Decision-Making Process. Annals of Tourism Research, 24(1), 178 - 191.Doi: 10.1016/S0160-7383(96)00049-7

PAGE, S. J. (2003).Tourism Management - Managing for Change. Oxford: Butterworth Heinemann.

PARK, J., WU, B., SHEN, Y., MORRISON, A. and KONG, Y. (2014).The Great Halls of China?Meeting Planners' Perceptions of Beijing as an International Convention Destination. Journal of Convention \& Event Tourism, 15, 244-270.Doi: 10.1080/ 15470148.2014.961669

PIKE, S. (2008). Destination Marketing - An Integrated Marketing Communication Approach. New York: Routledge.

SEVERT, D., WANG, Y., CHEN, P. and BREITER, D. (2007).Examining the Motivation, Perceived Performance and Behavioral Intentions of Conventions Attendees: Evidence from a Regional Conference. Tourism Management, 28, 399 - 408.Doi: 10.1016/j.tourman.2006.04.003

SHIN, Y. (2009). Examining the Link Between Visitors' Motivations and Convention Destination Image. Tourismos: An International Multidisciplinary Journal of Tourism, 4(2), 29 - 45.

SONG, H. and WITT, S. (2000). Tourism Demand Modelling and Forecasting: Modern Econometric Approaches. Oxford: Pergamon.

SOX, C. B., BENJAMIN, S., CARPENTER, J. and STRICK, S. (2013). An Exploratory Study of Meeting Planner and Conference Attendees' Perceptions of Sustainable Issues in Convention Centers. Journal of Convention and Event Tourism, 14 (2), 144 - 161.

VAR, T., CESARIO, F.andMAUSER, G. (1985). Convention Tourism Modelling. Tourism Management, 6(3) 195 - 204.Doi: 10.1080/15470148.2013.787662

WHITFIELD, J., DIOKO, L., WEBBER, D. and ZHANG, L. (2014). Attracting Convention and Exhibition Attendance to Complex MICE Venues: Emerging Data from Macao. International Journal of Tourism Research, 16, 169 - 179.Doi: 10.1002/jtr.1911

WOOTTON, G. and STEVENS, T. (1995). Business Tourism: A Study of the Market for Hotel-Based Meetings and its Contribution to Wales's Tourism. Tourism Management, 16(4), 305 313.Doi: http://dx.doi.org/10.1016/0261-5177(95)00020-O

WORLD TRAVEL \& TOURISM COUNCIL (2011).Travel \& Tourism Economic Impact 2011 World. Retrieved from http://www.foresightfordevelopment.org/sobipro/55/840-world-traveland-tourism-economic-impact-2011

YOO, J. J. and ZHAO, X. (2010).Revisiting Determinants of Convention Participation Decision Making. Journal of Travel \& Tourism Marketing, 27(2), 179 - 192.Doi: 10.1080/ 10548401003590369

ZHANG, H. Q., LEUNG, V.and QU, H. (2007).A Refined Model of Factors Affecting Convention Participation Decision-Making. Tourism Management, 28(4), 1123 - 1127.Doi: 10.1016 /j.tourman.2006.07.008 


\section{APPENDIX}

List of countries in the sample: Antigua and Barbuda, Algeria, Azerbaijan, Albania, Armenia, Angola, Argentina, Austria, Barbados, Botswana, Belgium, Bahamas, Bangladesh, Bosnia and Herzegovina, Bolivia, Benin, Byelarus, Brazil, Bulgaria, Canada, Cambodia, Chad, Sri Lanka, Congo, China, Chile, Cameroon, Colombia, Costa Rica, Central African Republic, Cape Verde, Cyprus, Denmark, Dominican Republic, Ecuador, Egypt, Ireland, Estonia, El Salvador, Ethiopia, Czech Republic, Finland, Fiji, France, Gambia, Gabon, Ghana, Grenada, Germany, Greece, Guatemala, Guinea, Honduras, Croatia, Hungary, Iceland, Indonesia, India, Israel, Italy, Japan, Jamaica, Jordan, Kenya, Kyrgyzstan, South Korea, Kazakhstan, Laos, Lebanon, Latvia, Lithuania, Lesotho, Luxembourg, Madagascar, Macau, Moldova, Mongolia, Malawi, Macedonia, Morocco, Mauritius, Malta, Oman, Maldives, Mexico, Malaysia, Mozambique, Vanuatu, Nigeria, Netherlands, Norway, Nepal, Nicaragua, New Zealand, Paraguay, Peru, Pakistan, Poland, Panama, Portugal, Papua New Guinea, Qatar, Romania, Philippines, Russia, Rwanda, Saudi Arabia, St. Kitts and Nevis, Seychelles, South Africa, Senegal, Slovenia, Sierra Leone, Spain, Serbia, St. Lucia, Sudan, Sweden, Syria, Switzerland, United Arab Emirates, Thailand, Tunisia, Turkey, Tanzania, United Republic of Uganda, United Kingdom, Ukraine, United States, Uruguay, St. Vincent and the Grenadines, Venezuela, Vietnam, Namibia, Swaziland, Zambia.

\section{AUTHORS' BIOGRAPHY}

PEDRO CARVALHO(Ph.D), is Adjunct Professor in the School of Technology and Management at the Polytechnic Institute of Vianado Castelo (Portugal). He received his Ph.D. from Extremadura University in Spain (2014), his MS from Portucalense University Infante D. Henrique (2004) and his BS from Lusophone University of Humanities and Technologies in Portugal (1999). Pedro's research is concerned with business tourism and relationship marketing. Currently, he teaches both undergraduate and graduate students in the areas of marketing. Address: School of Technology and Management, Polytechnic Institute of Viana do CasteloAvenida do Atlântico, 4900-348 Viana do Castelo, Portugal.

MIGUEL A. MÁRQUEZ (Ph.D), is Head of the Department of Economics at the University of Extremadura (Spain) and Scientific Secretary of the Spanish Association of Regional Science (AECR). He is Affiliate Research Professor at the Regional Economics Applications Laboratory (University of Illinois, USA). His major research work has covered a variety of topics related to both the field of regional economics and the field of economic growth, with a special focus on the design, implementation and application of economic models. He has published a number of papers in major journals (like European Economic Review, Environment and Planning A, Papers in Regional Science, etc...), participating in many different competitive research projects. Address: Department of Economics, University of Extremadura, Avda. deElvas, 06071 Badajoz, Spain

MONTSERRAT DÍAZ MÉNDEZ (Ph.D), has a degree in Administration and Business Management from the University of Extremadura and $\mathrm{PhD}$ in Business Administration from the University of Navarra. She is currently Professor of Communication and Ethics in the Faculty of Economics and Business Administration at the University of Extremadura. She conducted research at the University of Stockholm (Sweden) with the Professor Evert Gummesson and with the Professor Michael Saren at the University of Leicester (UK).Address: Department of Management, University of Extremadura, Avda. deElvas, 06071 Badajoz, Spain 